\title{
Taught to Remember? British Youth and First World War Centenary Battlefield $\underline{\text { Tours }}^{\mathbf{i}}$
}

\section{Dr Catriona Pennell, University of Exeter \\ Email: C.L.Pennnell@exeter.ac.uk}

Address for correspondence: Department of History, University of Exeter, Penryn Campus, Penryn, TR10 9FE, Cornwall

\begin{abstract}
Understanding the centenary of the First World War as a 'future making process' helps to explain the substantial focus of state-sponsored commemorative activity in Britain on young people. For it is they, according to many official outlets - as the 'next generation' - who have to bear the responsibility of carrying memory forward. The cornerstone of this activity is the UCL/Institute of Education (IoE) and Equity Travel First World War Centenary Battlefield Tours Programme (FWWCBTP), a national education initiative funded by the Department for Education (DfE) and Department for Communities and Local Government (DCLG). Between 2014 and 2019, the FWWCBTP will provide the opportunity for approximately 812,000 young people and teachers from every state funded secondary school in England to visit battlefields on the Western Front. Based on research data gathered predominantly from participants in the spring 2015 tours, this article seeks to explore the perspective of the programme participants, rather than the programme creators or accompanying teachers, to understand how they responded to the UK government's unprecedented attempt to engage young people in the history of the First World War via the vehicle of battlefield tourism. It explores possible tensions within the blending of education and remembrance, arguing that despite laudable intentions to encourage critical thinking about the First World War, for pupil participants the tour experience predominately emphasizes particular narratives of 'British' remembrance shaped around sacrifice, duty, and loyalty.
\end{abstract}

\section{KEY WORDS}

Youth, battlefield tourism, First World War, centenary, education, remembrance 


\section{Introduction}

Two paradoxical historical circumstances have aligned in contemporary British culture during the First World War centenary. On the one hand, there is unprecedented public interest in the conflict; on the other, there is a deep-rooted concern that the war is being forgotten, evaporating into the realms of historical amnesia once the finishing line of 11 November 2018 is crossed (Tanner, 2013). The period 2014 to 2018 might be best understood, therefore, as a moment of heightened anxiety about the future of First World War memory. If heritage is "defined as "what we value" or "what we wish to pass on to future generations"' (Deacon et al, 2004, p. 7) then the centenary of the First World War can be understood as a 'future making process' revealing palpable anxieties around loss and identity.

As a result of this foreboding threat of forgetting, a good degree of state-sponsored centenary activity in Britain has actively targeted young people for it is they - as the 'next generation' who have to bear the responsibility of carrying memory forward. The cornerstone is the UCL/Institute of Education (IoE) and Equity Travel First World War Centenary Battlefield Tours Programme (FWWCBTP), a national education initiative funded by the Department for Education (DfE) and Department for Communities and Local Government (DCLG) at a cost of around $£ 5.3$ million (Cabinet Office et al, 2012) ${ }^{\text {ii }}$ It is unsurprising that the British government sees battlefield tours of the Western Front as the most appropriate way to engage young people in the centenary of the First World War. Since the armistice in 1918, battlefield visits have been a staple feature of the way British people have engaged with the First World War (Lloyd, 1998; Pennell, 2018), increasing in popularity amongst schools since the 1990s (Bushaway, 2012).

Between 2014 and 2019, the FWWCBTP is providing the opportunity for a minimum of between two and four students and one teacher from every state funded secondary school in England to visit battlefields on the Western Front, approximately 8-12,000 young people and teachers in total. ${ }^{\text {iii }}$ Pupils are drawn predominantly from Key Stage Three, the main level where First World War History is taught and a crucial moment before History becomes an optional subject in the national curriculum (Einhaus \& Pennell, 2014, p. 16). ${ }^{\text {iv }}$ Tour seasons are split into spring and autumn and approximately fifteen tours take place each season. Between 80 and 120 participants are involved in a single tour travelling in two or three coaches. Each coach is led by an accredited International Guild of Battlefield Guide (GBG) accompanied by a serving soldier and a member of Equity staff. Each tour is supported by a 
senior member of the FWWCBTP IoE team as well as a mobile team of senior army officers who are there, primarily, to support their junior personnel. At the time of writing, the military involvement in the FWWCBTP was not widely advertised but it forms part of the British army's Operation REFLECT, designed to mark the centenary of the First World War and the British army's participation in this conflict. ${ }^{\mathrm{v}}$

Each trip lasts four days, starting in the UK (Kent) with orientation, team-building and preparatory activities, including an internet-based research exercise into a local soldier and an object handling session of First World War military ephemera led by the GBG, supported by members of the British army. Two and a half days are then spent in Belgium and France. Although the tour content varies slightly according to specific timings and prominent anniversaries (e.g. Passchendaele in 2017), all students visit the major British memorial sites - the Menin Gate, the Thiepval Memorial and the largest Commonwealth War Graves Commission (CWGC) cemetery at Tyne Cot - the German war cemetery at Langemark, as well as at least one historical museum in Belgium. ${ }^{\mathrm{vi}}$ All groups participate in the Last Post ceremony at Menin Gate with two students per coach selected to represent the programme by laying a wreath in school uniform alongside a serving soldier. After the service, there is a chance to buy chocolate and souvenirs in Ypres. Most groups will participate in a claymodelling activity at the charity 'Coming World Remember Me'. vii Another evening is taken up with a military-led activity at the hotel, which has evolved over time but centres on the theme of 'the British army: then and now'. On return home, all groups are expected to use their visit as the catalyst for a commemorative project in their local community (Legacy 110). The programme is supported by a range of materials including teacher Continued Professional Development (CPD) training, teaching resources, and podcasts by leading historians summarising key historiographical debates. ${ }^{\text {viii }}$ If the upper target of 12,000 pupils is reached, the FWWCBTP will be the largest organised visit to the Western Front, more than the Royal British Legion pilgrimage to the battlefields between 4 and 8 August 1928 in which around 10,000 pilgrims participated (Lloyd, 1998, p. 33). Its focus on young people, the involvement of the Ministry of Defence (MoD), and the emphasis on a post-visit commemorative project underscore the unprecedented nature of this state-led initiative. It is also the most significant centenary initiative funded by the DfE.

The stated objectives of the FWWCBTP are to both expand young people's knowledge base (ensuring pupils 'acquire a deeper understanding' of the war based on the 'latest scholarship') 
and to create a generation who will carry the memory of the war forward (pupils will participate 'in remembrance ceremonies' and create 'an enduring legacy' through 'post-visit commemorative projects with their communities'). ${ }^{\text {ix }}$ But can history education and remembrance be blended so easily? To explore this question further, it is useful to first unpack what we understand by both these terms. According to the latest National Curriculum History Programme of Study for Key Stage 3, a 'high-quality history education':

will help pupils gain a coherent knowledge and understanding of Britain's past and that of the wider world. It should inspire pupils' curiosity to know more about the past. Teaching should equip pupils to ask perceptive questions, think critically, weigh evidence, sift arguments, and develop perspective and judgement. History helps pupils to understand the complexity of people's lives, the process of change, the diversity of societies and relationships between different groups, as well as their own identity and the challenges of their time (Department for Education, September 2013).

This statement is in line with latest scholarly opinion on history education. Rather than seeing school history as about imbuing young people with a master narrative about the past, favourable amongst certain members of the ruling Conservative Party including former Secretary of State for Education, Michael Gove, 'disciplinary history' is about teaching young people to think critically and historically (Seixas, 2000). ${ }^{\mathrm{x}}$ Scholars argue that students should learn how stories about the past developed in the first place and understand the relationship between historical evidence and the construction of accounts. ${ }^{\mathrm{xi}}$ This process 'necessarily involves multiple perspectives, not only so that students understand how the same evidence can lead to divergent interpretations, but also so they recognize that people in the past held different outlooks than we do today and may have perceived events differently than we do' (Barton \& Levstik, 2003, p. 358).

While a vast scholarship exists on memory, commemoration, and remembrance, one of the most important contributors to the study of memory - Jay Winter - defines remembrance as: 'public recollection. It is the act of gathering bits and pieces of the past, and joining them together in public...Collective memory is constructed through the action of groups and individuals in the light of day' (Winter \& Sivan, 1999, p. 6). ${ }^{\text {xii }}$ Winter specifically encourages the use of the term 'remembrance' (which has more active connotations) over 'memory' (which implies something static) (Heathorn, 2013; Winter, 2006). Both education and remembrance are highly constructed depending on certain political, societal, cultural and mental conditions. Inevitably, certain narratives (or memories) are prioritised over others. While the resulting assemblage is not pure fiction they are both implicitly but unavoidably 
ideologically charged. Yet education and remembrance are distinguishable by their goals and effects. While educationalists agree that learning about the past should - at its heart encourage a sense of critical questioning and independent thinking, the group mentality of socially constructed and politicised rituals of remembrance can potentially close down such spaces leading to a 'one size fits all' response of 'we must remember'. Particularly in the case of 'official' remembrance (which describes the vision of the past sanctioned by the state and/or political institutions), the object that is to be remembered is pre-defined; there is no scope to proffer alternatives at a nationally staged ritual of commemoration (Heathorn, 2013).

The individuals responsible for the design of the FWWCBTP were sensitive to the political context that imbibes educational and commemorative activity during the centenary, such as Gove's controversial interjection in January 2014 criticising a particular cultural memory of the war that denigrated 'patriotism and courage by depicting the war as a "misbegotten shambles"' when, in fact, it was "plainly a just war to combat aggression by a German elite bent on domination' (Shipman, 2 January 2014). Encouraged by the latest developments in history education in England, especially a 2013 National Curriculum heavily influenced by the principles of 'disciplinary history', the FWWCBTP team endeavoured to construct 'a program that was intellectually robust, age-appropriate, academically sound and in keeping with the innovative developments of pedagogical practice in history teaching over the past five decades' (Foster, 2017, pp. 189-190). The programme team were conscious of the limits of their remit - not least the short amount of time the pupils have on the tour and relatively small amount of money provided by the DfE to run the programme - and that no single educational initiative is ever going to be a 'quick fix' in developing in young people a sophisticated conceptual understanding of the complexities of historical study. This article does not dispute the laudable intentions of the programme - to encourage critical thinking about the First World War and the ways it is remembered - but instead of relying on the perspective of the programme creators or accompanying teachers, it switches focus to the programme participants to understand how they responded to the UK government's unprecedented attempt to engage young people in the history of the First World War via the vehicle of battlefield tourism.

The article is based on unpublished research data submitted, confidentially and in greater analytical detail than can be afforded here, to the FWWCBTP team as part of a partnership agreement with the author to support their commitment to improving pupil experience over 
the programme life-cycle. What follows is not intended to be a comprehensive statistical analysis. Instead, I wish to contribute to a critical discussion of history education, memory and remembrance, and military-centric heritage using empirical data gathered predominantly from participants in the spring 2015 tours via a combination of basic quantitative (surveying) techniques and qualitative approaches influenced by methodologies established in the fields of critical heritage studies, cultural and historical geography, and, where relevant, tourism research. ${ }^{\text {xiii }}$ Between 6 February and 25 March 2015, 790 pupils from across England travelled to Belgium and France as part of the FWWCBTP. All participating pupils were invited to complete a 34-question paper survey on the final evening of the tour. ${ }^{\text {iv }}$ Embedded ethnographical observation took place during three tours in February 2015, 2016 and 2017 allowing the author the opportunity to speak informally to pupils, teachers, battlefield tour guides, and serving army personnel accompanying the tour groups. Two formal focus groups were hosted (led by the author) with student participants in July 2015 to follow up on the survey and the issues it raised in more depth. ${ }^{\mathrm{xv}}$ As a result, this article explores possible tensions within the blending of education and remembrance. How have pupils responded to the educational content of the FWWCBTP? What narratives of the war are included and excluded? How far are critical enquiry skills into the history of the war being developed by pupil participants? To what extent are they being taught to remember? What are the implications of this?

\section{Content: 'Wow. It's one thing seeing 12,000 written in a book, but it's another thing seeing 12,000 headstones ${ }^{\mathrm{xvi}}$}

The FWWCBTP has been recognised by a number of external bodies for its educational content as well as being rated highly by both teacher and pupil participants. ${ }^{x v i i}$ One pupil survey respondent described the tour as 'very informative, eye opening'. A Year 10 pupil felt the trip was 'very important' because 'people should see [the cemeteries] first hand to understand [the war] better and the mark it left'. $98.8 \%$ of survey respondents stated they would recommend the FWWCBTP to a friend. The top five 'best' aspects of the tour were: 1) seeing the different cemeteries/memorials; 2) participating in the Last Post ceremony at Menin Gate; 3 ) making new friends; 4) learning new information/better understanding about the war; 5) museums visited. The majority of the responses to this question relate to the substance of the tour programme, particularly the places visited. However, it is also worth noting the presence, albeit less frequently, of the social and logistical elements of the tour (such as making new friends; shopping in Ypres; eating Belgian waffles; free Wi-Fi in the 
hotel; going on the Eurostar) which echo other investigations into battlefield visits by Baldwin and Sharpley (2009) and Scates (2006) whereby the young people have a 'hybrid experience' that is at once student, pilgrim, and tourist (Pennell, 2018). It also highlights how the programme takes into account the need for 'down time' in order to engage more productively with the educational aspects of the tour.

According to the programme leaders, the tour is not just another 'site seeing coach trip' because the content is designed around three key enquiry questions:

1. How did the First World War affect ordinary people?

2. Was the Somme 1916 a disaster?

3. Is remembrance more or less important 100 years on?

The questions form the basis of the two-and-a-half-day tour on the Western Front with the locations chosen because of their relevance to the questions and to ensure pupil engagement at each site (Bendry, 2017). Pupils consider the impact of the war on British society by visiting Lijssenthoek Military Cemetery, site of Commonwealth casualty clearing stations over the course of the war. The question of the 'learning curve' - that the British military underwent a process of improvement based on battlefield experience - is considered at various sites around the Somme. The theme of remembrance is returned to at the final tour stop, Tyne Cot Cemetery. As part of the preparation in Kent, students are assigned a local soldier to research, discussed below, in order to encourage the students to appreciate that a cemetery is more than thousands of headstones and that every individual came from a community left devastated by the war.

The FWWCBTP provides pupil participants with detailed information about aspects of the First World War that are included in the tour itinerary - primarily the battlefields, memorials, cemeteries and preserved trenches, as well as the museums that now exist, in some of the major areas that the British army saw action in France and Belgium between 1914 and 1918. Almost $94 \%$ of survey respondents felt their 'knowledge and understanding of the First World War' had increased 'quite a lot more' or 'a great deal more' as a result of participating in the tour. Students were asked to list the three key pieces of new information they had learnt about the First World War as a result of the tour (Q20). The top five results were: 1) major battles; 2) scale of loss; 3) trenches/dugouts; 4) significance/rituals of remembrance; 5) equipment/weapons/technology. It corresponds that a tour that places a good deal of 
emphasis on the Battle of the Somme and focuses on visits to major memorial sites to the missing (Thiepval and the Menin Gate), as well as some of the largest British commonwealth cemeteries in the world (Lijssenthoek and Tyne Cot), should provoke in survey respondents a sense of learning about major British battles, the scale of the dead and missing in the First World War, and the significance of (and rituals involved in) acts of remembrance at these sites. Yet a large number of survey respondents evidenced an understanding of the war that went beyond these areas. $73 \%$ of survey respondents agreed or strongly agreed with the statement 'I now realise that the soldiers did not spend all their time fighting in the trenches' and over $91 \%$ of survey respondents felt they had 'a better understanding of the military tactics used during the war'. In the free-text comments, a number of pupils felt they had learnt about the geographical spread of the war ('there was more relationships involved other than British and Germans [sic]') and the contribution made by colonial troops of the British empire, particularly Indian soldiers (stemming from their visit to the Neuve-Chapelle Indian Memorial). Almost $81 \%$ of survey respondents agreed or strongly agreed with the statement that the tour had helped them develop an understanding of "why the First World War is called a world war'. For a tour that focuses solely on the battlefields (and the military dead) it is also promising that these comments reveal pupils were thinking about the impact the war had on people at home (particularly their local communities), as well as French and Belgian civilians who lived near the battle sites.

However, the tour is limited in the extent to which it can deepen pupils' understanding of the First World War much beyond the Western Front, owing to the nature and logistical constraints of the programme itinerary. The programme tries to draw attention to 'lesser known' aspects of the experience of the First World War but with only two nights abroad the focus has to remain on traditional topics, placing emphasis on the Somme as the central British experience, Britain as the main protagonist, and the main actors involved being the soldiers and the soldier-dead. Combat experience on the Western Front, and specifically combat mortality, is privileged, despite the fact that around $88 \%$ of soldiers who fought in the British Army during the First World War survived (Watson, 2006, p. 247). Any tour of the military cemeteries and memorials of the Western Front is going to struggle to open pupils' eyes to experiences of women on the home front beyond those that experienced bereavement. The visit to the Neuve-Chapelle Indian Memorial or the pointing out of Indian names on the Menin Gate memorial is designed to broaden young people's understanding of the global nature of the conflict. However, limits on time mean that a heroic 'martial races' narrative of 
colonial troop experience can emerge which overlooks more complex and contentious issues such as wartime racial hierarchy, exploitation and mistreatment (Barrett, 2007, Levine, 1998). These additions are susceptible to accusations of tokenism and 'colonial nostalgia' that have been given renewed zeal in British politics since the vote to leave the European Union in July 2016. ${ }^{\text {xiii }}$ One of the lowest response rates to Q20 was 'Remembrance of German dead', selected at a frequency rate of $1.54 \%$ suggesting that despite the attempt by the programme team to incorporate multiple perspectives, limits of time mean insufficient mediation by the students on the impact of the war on Germany, which is key to the understanding of European politics in the interwar period. The language used, on occasion, by some of the GBG when describing battlefield encounters between the British and German armies compounds this concern. In all tour observations between 2015 and 2017 personal pronouns - 'us' (the British troops) and 'them' (the German troops) - were employed to describe positions and ground gained/lost. This could have a polarising effect in the minds of some pupil participants and was evident in the language some pupils employed to describe the events they had heard about. One Year 11 pupil expressed concern about this; by focusing on the British experience and British soldiers 'we were sort of given impression that it was us against them which I feel is not how you should look at it a hundred years on.' ${ }^{\text {xix }}$

\section{Methods of Learning: 'I think it's going to be really emotional' ${ }^{x x}$}

The way that the students interact with the material they are presented with on this tour is as important as the content. The majority of the tour content is delivered via on-site presentations, in the case of battlefields, memorials and cemeteries, and freedom to explore other sites (such as the museums) under the guidance of an accompanying teacher/guardian. These visits are supported by the weighty 145-page tour booklet supplied at the start of the tour, as well as two DVD presentations shown on the coach during the two long drives of the tour (from Calais to Ypres and from Ypres to the Somme). The booklet is designed to help prepare students for the visit and for them to refer to afterwards, rather than an on-site resource. The degree to which students engage with this resource is dependent on individual motivation and the guidance of their teacher/accompanying adult. Another important method of engagement is object handling. At the start of the tour the GBG, in conjunction with the army personnel, lead an object handling session where students examine First World War trench items such as grenades, rifles, Princess Mary Christmas Gift Fund box, spoons, and wire cutters. On the final evening of the tour, the military, supported by the GBG and members of the IoE team, lead a session on military kit comparison 'then and now'. This is a 
chance for students (and teachers) to dress up in various kit from the First World War era and the present day. During the three tour observations made by the author, this activity was accompanied by face painting with camouflage cream (2015), a high-energy team 'gas mask' relay race (2016), and the distribution of British army branded 'goodies' like pencils and glow sticks (2017). ${ }^{\mathrm{xxi}}$

The involvement of the MoD is one of the features of the FWWCBTP that makes it different to a standard battlefield tour. While limited information is available about the MoD's involvement prior to departure, the serving soldiers are introduced in the opening briefing in Kent as one of the four sets 'leaders' involved in the tour. For many young people, their involvement was a stand-out feature helping them to compare the features of warfare at the turn of the $20^{\text {th }}$ century and today. According to one 2015 focus group participant: 'I felt on the trip where if there hadn't been military people it wouldn't have been understood quite as well.' Forging a closer sense of connection between the military and civil society has its benefits. In a society where 'experiences' of military violence are readily available to young people, through social media, films, and computer games, the army remains a small and distant part of most people's lives, potentially making deployment without due care and attention easier.

However, the 2015 focus groups raised an interesting discussion about the implications of serving soldiers accompanying pupils on the tour and the impact this might have on critical reflection. When asked about aspects of the tour they would seek to change, two Year 11 pupils immediately responded with 'the presence of our military'. When asked to develop this point, they talked about how it continued a sense of 'us' versus 'them' with Britain being victorious over Germany. They asked why the FWWCBTP had not invited other military representatives on the tours, such as serving German soldiers or injured veterans. Another student felt that the presence of the military closed down the space to ask interrogative questions. In their view, no one was going to respond to the third enquiry question 'should we remember' at Tyne Cot in the negative with a serving soldier within earshot. However, only two students out of all those surveyed and interviewed between 2015 and 2017 raised any concern about the presence of British military personnel on these tours.

In line with a broader educational emphasis on the concept of historical empathy in developing critical thinkers (Barton \& Levstik, 2004; Foster, 2009), one of the main aims of 
the tour programme is to enable pupils to develop a personal connection to the First World War. On arrival in Kent, the students 'adopt' and research, using web resources, a local soldier; a casualty of the First World War listed or buried at Tyne Cot or Thiepval memorial that has some association with the local area where the student's school is based. Information gathered often reveals how closely the students' lives interconnect with this dead soldier through locality. The students continue to track 'their' soldier throughout the tour often culminating in the laying of a wooden cross (provided on the coach with a small donation to the Royal British Legion) at Tyne Cot or Thiepval. For one Year 10 pupil participant, the highlight of the tour had been finding the grave of a local soldier they had researched in advance. For her, it meant that the First World War 'was kind of related to us more...like the people from our area who were actually there fighting for like our country'. ${ }^{x x i i}$ Almost 63\% of survey respondents agreed or strongly agreed that the battlefield visits had provided them with a 'better understanding of how the war affected my local community'.

Utilising the individual and local as compelling 'hooks' can be understood as part of the wider growth of interest in family history in recent years (McCartney, 2014; Wallis, 2015) and is a key pedagogical tool to engage the interest of young people in the past, particularly if they have no personal connection to the event. As McCartney outlines 'at a time when widespread knowledge of the war is fading, and the majority of the population has only a vague grasp of its history, genealogical research provides an accessible route to learning about the war' (McCartney, 2014, p.305). However, the approach does have a number of limitations. Firstly, individual stories cannot provide the detailed information required to paint a complex picture of the war and its context. Secondly, it can provoke an emotional reaction rather than a critically reflective one. Two students from London who participated in the February 2015 tour described how they felt when they found the grave of the soldier they had been assigned:

we were really emotional...Although we had seen thousands of graves over the course of the Battlefields Tour, "meeting" George made us very sad and really think about his sacrifice. We felt in some way, we knew him... (cited in Bendry, February 2017).

After spending three days researching some basic information about Private George Baxter Lowson, the students felt an extremely strong connection to this man. But any thoughts they had about this dead soldier were imagined; even researchers who dedicate their careers to understanding past lives using contemporary documents and a wealth of secondary material, can never claim to know what people thought and felt in the past. It is more likely that these 
young men were projecting their own feelings and attitudes towards the First World War, and perhaps war in general, onto a historical figure (McCartney, 2014). The two students were so moved by finding Lowson's grave that on return to school, they composed a song 'My Mate George' as part of their Legacy 110 project, which has been celebrated as 'inspirational' via regional and national media. ${ }^{\text {xiii }}$ The lyrics reveal the degree to which the students had formed an image of this soldier as a brave but powerless victim, reinforcing popular views of the war as a tragedy for innocent young men. For these students, this soldier's predominant role was to die, although in reality it would have been to kill.

As an act of remembrance this song is both understandable and effective; one hundred years on, any remembrance activity is going to be about imagined connections to the past. Taking into account that these two pupils attend a specialist school for young people with a range of educational needs, the writing of the song is evidence of a significant developmental experience. But how do we position it versus the goals of history education detailed above? The pupils' response to 'finding' Private Lowson raises concerns about their awareness of war (and reactions to war) being historically and culturally contingent (Bourke, 1999). They appear to assume that Private Lowson is the same as them because he is from the same locality. Yet a critically reflective response would encourage them to consider how there is no universality of war experience; while Private Lowson may have recognised some of the sentiments in their song, he may also have seen them as alien. Presenting dead soldiers as 'like us' smoothes over the political and historical complexities of First World War history, taking 'the history out of commemoration' (Ashplant et al, 2000, p. 11).

\section{Implications: 'We owe them everything' xxiv}

Undoubtedly, the tours can be described as educational, verified by positive teacher feedback and the number of education awards received since 2014. The tour content develops pupil participants' understanding of the First World War, illuminating two-dimensional textbook 'facts' regarding death-toll, societal impact, and battlefield terrain. The value of the programme - in the way it puts students directly in contact with historical artefacts and sites from the past, consolidating understanding and fuelling enthusiasm for a subject - is no different to the accepted benefits of field trips more generally (Wilson \& Hollis, 2007). Most students return with a deeper understanding of certain aspects of the First World War, particularly its immense human cost, what life was like in the trenches, and the military objectives of the Battle of the Somme. In addition, the tour programme tries to develop 
pupils' research skills such as 'reading' a headstone and using internet resources such as the CWGC and the IWM's Lives of the First World War databases. ${ }^{\mathrm{xxv}}$

However, choices of emphasis have to be made, conditioned by variables such as time, location, and cost. While the tours are not the only place that young people encounter the history of the First World War, and there remains the possibility that broader issues, context, and complexity are being handled back in the classroom, these choices need to be acknowledged, as do their potential consequences. ${ }^{x x v i}$ The vast majority of the tour focuses on events and sites relevant to the British experience of war. Issues of non-military participation, gendered, and non-white perspectives are inevitably forced to the periphery of the tour content because of the choice of location and sites visited (military cemeteries/memorials in Western Europe). Questions relating to the war's origins, aims, prewar society (including Germany), and the European and global rationale for war in 1914 are all absences which hinder a sophisticated understanding of the war as a world war, linked to trade and empire. While the visit to Langemark is important, there is a stark imbalance between attention paid to the scale of loss for Britain and that of other belligerents. The impact of the war on Germany is key to understanding European politics in the interwar period and the rise of Nazism; representing the Germans briefly as 'the other' and sometimes the 'dead other' is not enough.

Limited time on the tour means that there is insufficient space for critical reflection on the way narratives of the past are constructed. Space for critical thinking can be shut down by the sheer emotion of the sites visited; it is hard to feel anything other than a sense of tragedy and veneration when standing in the neatly kept cemeteries of the CWGC, in front of a sea of headstones (Englund, 2011). This restriction is exacerbated by the presence of British military personnel. No student interviewed as part of this research felt comfortable in openly stating an opinion, with a British soldier potentially within earshot, which critiqued national ceremonies of remembrance or questioned the degree of emphasis the UK government is placing on centenary commemorations between 2014 and 2018. The programme's decision to utilise local and individual 'hooks', particularly the 'adopt' a soldier exercise, implicitly creates a sense of 'loyalty' to dead (and living) British soldiers and assumes a connection to the past that does not necessarily exist. While an innovative attempt to capture student attention, it can also act as a disabler of critical reflection. The inclusion of MoD led activities, such as the British army 'then and now' could also underscore a sense of 'nothing 
much has changed' amongst the pupil participants, assuming an ahistorical sense of closeness to the past. Moreover, it could contribute to the building of a narrative of 'normalised' continuous warfare in British history, representing the First World War as the predecessor of later conflicts (Iraq, Afghanistan) and introducing the modern British army as the rightful successor and guardian of British remembrance (Danilova, 2015).

The lack of space for critical reflection is in stark contrast to the emphasis placed in the tour content on remembrance practices. Despite 'should we remember 100 years after the event' being posed as a question, the tour - from its starting point - is designed to instil a sense of 'duty' to remember amongst the pupil participants and verses pupils in the language, rituals, and emblems to participate in such commemorative activity. On the first day, participants are told how they are expected to engage with the Legacy 110 aspect of the tour on their return home. ${ }^{\text {xxvii }}$ Acts of commemoration and remembrance are scheduled into the tour itinerary (at Menin Gate and Tyne Cot, and as part of the 'Coming World Remember Me' art project), as are personal rituals of remembrance (finding their 'adopted' soldier or 'old boy' of the school and laying a wooden cross), all underscored by the 25-minute CWGC produced DVD 'A Debt of Honour. ${ }^{\text {xxviii }}$ To this end, the tour is very successful. $90.5 \%$ of survey respondents stated that the purpose of visiting the First World War battlefields was 'to remember the dead'. This response rate was higher than any of those dealing with explicitly educational issues such as learning about British history, seeing the battlefields of the Western Front, or learning about the history of Europe. $82 \%$ of survey respondents agreed or strongly agreed that remembering the First World War was important because 'it would be disrespectful not to'. For one focus group participant, raising an objection to remembrance during the tour was equivalent to "walking into a church and you know saying that you love the devil and you hate god and everything. 'xxix The majority of students stated that the tour had made them more likely to be involved in commemorative activity connected to the First World War in the future. A lot of pupil participants, after witnessing the Last Post ceremony at the Menin Gate, felt galvanised to increase remembrance activity in the UK. As one Year 10 pupil explained:

Belgian people remember the dead every day whereas British people do it once a year. This is wrong. People should be remembering more often. Why leave it to the Belgians? These men are dead so that we're alive today. We need to remember more. ${ }^{\mathrm{xx}}$

The risk, therefore, is that rather than encouraging young people to think critically about the past, the tours are emphasizing a particular narrative of remembrance shaped around 
sacrifice, duty, and loyalty. As two Year 12 pupils recalled, the overwhelming feelings they had at Tyne Cot on finding the grave of a local soldier were gratitude and reverence: 'we're here 100 years [later] where he lost his life fighting for our country and now we were standing there freely'; 'it was immense. Like a feeling of gratitude and just [she sighs] appreciation of their bravery and their sacrifice.' ${ }^{{ }^{x x i}}$

\section{Conclusion: 'Why do we do it?'}

This article has used empirical data gathered using a combination of basic quantitative methods and qualitative analysis of the FWWCBTP - the youth 'flagship' of the UK government's centenary programme - to assess the tensions revealed when attempting to combine history education and remembrance. There is a convincing argument that such tensions are a product of broader structural constraints, predominately the limited time and funding that has been made available for this educational initiative. This is a lesson that applies to centenary initiatives more broadly; often it is the unintended and unalterable consequences of the medium that shape the outcome no matter how laudable the intentions. Yet there remains an inherent contradiction at the heart of the programme's 'marrying' of education and remembrance, an inevitable result of the programme's timing: during the war's centenary, with the inevitable emphasis that state funders have placed on remembrance. ${ }^{x x x i i}$ Government-sponsored battlefield tours during the centenary are potentially contributing to the convergence - or even replacement - of history education with a military-centered concept of citizenship where hierarchies of Britishness based on gender, ethnicity, race, and military service are prioritised over alternative war experiences (Danilova, 2015). The involvement of the $\mathrm{MoD}$ means this activity should be considered within the context of broader government initiatives of bringing a military ethos into schools (Basham, 2016). Limitations of time and space can therefore also be interpreted as 'excuses' to legitimate a one-dimensional approach to citizenship and the study of war history.

Returning to Deacon et al's definition of heritage, referenced at the start of this article: what are these tours telling young people about who they are and where they should go in the future? In many ways, and despite intentions to the contrary, the tour content is reaffirming particular narratives of Britain's past; that the First World War was a just and necessary conflict, fought at huge cost by brave and innocent young men. The focus of predominantly British sites of remembrance and battlefield landscapes discussed primarily in terms of Britain's military contribution, presented in language that often slipped into 'us' (British 
soldiers) versus 'them' (the German enemy), on a tour accompanied by serving military personnel in British uniform is in danger of becoming part of an 'our island story' approach to history education. As Benedict Anderson argued, the tombs and cenotaphs of unknown soldiers are 'the most arresting emblems of the modern culture of nationalism' (Anderson, 1991, p. 9) and the cult of the fallen soldier is ever present in the content of these centenary tours. But if nationalism allows a community to stretch back into an immemorial past, it also enables a vision of an indefinite future, transcending the finitude of each individual (BenAmos, 2003). On this issue, the students were less sure. When students were asked to reflect on the purpose of the tours, many responded confidently that remembering could prevent future wars. When pressed further, referring to ongoing conflicts experienced first-hand by many of the soldiers who accompanied the tour, the students floundered. 'Remembrance isn't working' admitted one Year 10 pupil reluctantly; 'we have all the evidence there and we know that it's tragic and futile but we still do it'. ${ }^{\text {xxiii }}$ Another Year 12 student questioned: 'they [First World War soldiers] fought for freedom but we're still fighting and we're still losing lives, we're still making sacrifices, then why do we do it?...Is it just an endless cycle? 'xxxiv This highlights the inherent tension in modern British society between an obsessive desire to 'remember' while simultaneously 'forgetting' or ignoring the ambivalent causes of modern conflict: 'this symbolic separation allows for the powerful illusion of remembrance without politics' (Danilova, 2015, p. 208). The tours are teaching young people to remember a predominantly British experience of the First World War, to ensure that the 'next generation' engages in remembrance practices - but for what purpose is not entirely clear to the students. 


\section{References}

Anderson, B. (1991). Imagined Communities: Reflections on the Origins and Spread of Nationalism. London: Verso.

Ashplant, T.G., Dawson, G. and Roper, M. (Eds.) (2000). The Politics of War Memory and Commemoration. London: Routledge.

Baldwin, F. and Sharpley, R. (2009). Battlefield Tourism: Bringing Organised Violence Back to Life. In R. Sharpley and P.R. Stone (Eds.), The Darker Side of Travel: The Theory and Practice of Dark Tourism (pp. 186-206). Bristol: Channel View Publications.

Barrett, M. (2007). Subalterns at War, Interventions, 9:3, pp. 451-474.

Barton, K.C. and Levstik, L.S. (2003). Why don't more history teachers engage students in interpretation?, Social Education, 67:6, pp. 358-361.

Barton, K. C., \& Levstik, L. S. (2004). Teaching history for the common good. Mahwah, NJ: Lawrence Erlbaum Associates.

Basham, V. (2016). Raising an Army: The Geopolitics of Militarizing the Lives of WorkingClass Boys in an Age of Austerity, International Political Sociology 10, pp. 258-274.

Ben-Amos, A. (2003). War commemoration and the formation of Israeli national identity, Journal of Political and Military Sociology, 31:2, pp. 171-195.

Bendry, S. (February 2017). Learning beyond the battlefield, Leader: The Magazine for School and College Leaders. Retrieved from http://www.leadermagazine.co.uk/articles/learning beyond the battlefield/

Bourke, J. (1999). An Intimate History of Killing: Face-to-Face Killing in Twentieth Century Warfare. London: Granta Books.

Bushaway, B. (12 September 2012). History and the Role of the Field Trip: The Battlefield Visit. Unpublished paper presented at the $14^{\text {th }}$ Annual Higher Education Academy Teaching and Learning Conference, London. Shared with kind permission of Pat Bushaway.

Cabinet Office, Prime Minister's Office, 10 Downing Street and The Rt Hon David Cameron MP. (11 October 2012). Speech at Imperial War Museum on First World War centenary plans. Retrieved from https://www.gov.uk/government/speeches/speech-at-imperial-warmuseum-on-first-world-war-centenary-plans

Cooper, H. and Chapman, A. (Eds.). (2009). Constructing History 11-19. London: SAGE.

Danilova, N. (2015). The Politics of War Commemoration in the UK and Russia.

Basingstoke: Palgrave Macmillan.

Deacon, H. with Dondolo, L., Mbulelo, M. and Prosalendis, S. (2004). The subtle power of intangible heritage: legal and financial instruments for safeguarding intangible heritage. Cape Town, South Africa: HSRC Publishers.

DfE, Statistical First Release: Schools, pupils and their characteristics: January 2015 (SFR16/2015). Retrieved from https://www.gov.uk/government/uploads/system/uploads/attachment_data/file/433680/SFR1 6_2015_Main_Text.pdf

Dunkley, R., Morgan, N. and Westwood, S. (2011). Visiting the trenches: exploring meanings and motivations in battlefield tourism, Tourism Management, 32, pp. 860-68. 
Einhaus, A-M. and Pennell, C. (May 2014). The First World War in the Classroom: Teaching and the Construction of Cultural Memory - Final Project Report. Retrieved from http://ww lintheclassroom.exeter.ac.uk/wp-content/uploads/2014/06/FWW-in-the-Classroomfinal-project-report.pdf

Englund, P. (2011). Touched from a distance, History Today, 61:11, pp. 3-4.

Foster, S. (2009). Using Historical Empathy to Excite Students about the Study of History: Can You Empathize with Neville Chamberlain?, The Social Studies, 90:1, pp. 18-24.

Foster, S. (2017). Teaching About the First World War in England: Exploring Controversy and Competing Historical Interpretations. In H.Å. Elmersjö, A. Clark and M. Vinterek (Eds.), International Perspectives on Teaching Rival Histories: Pedagogical Responses to Contested Narratives and the History Wars (pp. 181-205). London: Palgrave Macmillan.

Gove, M. (5 October 2010). Michael Gove: All pupils will learn our island story [Speech at Conservative Party Conference]. Retrieved from http://conservative-

speeches.sayit.mysociety.org/speech/601441

Heathorn, S. (2013). Haig and Kitchener in Twentieth-Century Britain: Remembrance, Representation and Appropriation. Farnham: Ashgate.

Hopkins, P.E. (2010). Young People, Place and Identity. Oxford: Routledge.

Husbands, C., Kitson, A., and Pendry, A. (2003). Understanding History Teaching: Teaching and learning about the past in secondary schools. Maidenhead: Open University Press.

Iles, J. (2006). Recalling the Ghosts of War: Performing Tourism on the Battlefields on the Western Front, Text and Performance Quarterly, 26:2, pp. 162-180.

Iles, J. (2008). Encounters in the Fields - Tourism to the Battlefields of the Western Front, Journal of Tourism and Cultural Change, 6:2, pp. 138-154.

Lee, P. (2011). History education and historical literacy. In I. Davies (Ed.), Debates in History Teaching (pp. 63-72). Oxford: Routledge.

Levine, P. (1998). Battle Colors: Race, Sex, and Colonial Soldiery in World War 1. Journal of Women's History, 9:4, pp. 104-130.

Lloyd, D. W. (1998). Battlefield Tourism: Pilgrimage and the Commemoration of the Great War in Britain, Australia and Canada, 1919-1939. Oxford: Berg.

McCartney, H.B. (2014). The First World War Soldier and His Contemporary Image in Britain. International Affairs, 90:2, pp. 299-315.

Miles, S. (2013). From Hastings to the Ypres salient: Battlefield tourism and the interpretation of fields of conflict. In R. Butler and W. Suntikul (Eds.), Tourism and War (pp. 221-231). London: Routledge.

Mycock, A. (2014). The First World War Centenary in the UK: 'A Truly National Commemoration'? The Round Table: The Commonwealth Journal of International Affairs, 103:2, pp. 153-162.

Pennell, C. (2016). Learning Lessons from War? Inclusions and Exclusions in Teaching First World War History in English Secondary Schools, History and Memory, 28:1, pp. 36-70.

Pennell, C. (2018). "To leave a wooden poppy cross of our own": First World War battlefield spaces in the era of post-living memory. In. J. Wallis and D.C. Harvey (Eds.), Commemorative Spaces of the First World War: Historical Geographies at the Centenary (pp. 173-189). Oxford: Routledge. 
Scates, B. (2006). Return to Gallipoli: Walking the Battlefields of the Great War. Cambridge: Melbourne University Press.

Seaton, A.V. (2000). “Another Weekend Away Looking for Dead Bodies...": Battlefield Tourism on the Somme and in Flanders, Tourism Recreation Research, 25:3, pp. 63-77.

Seaton, A.V. (2002). Observing conducted tours: The ethnographic context in tourist research, Journal of Vacation Marketing, 8:4, pp. 309-319.

Seixas, P. (1999). Beyond "content" and "pedagogy": In search of a way to talk about history education, Journal of Curriculum Studies, 31:3, pp. 317-337.

Seixas, P. (2000). Schweigen! die Kinder! or Does Postmodern History Have a Place in the Schools? In P. Stearns, P. Seixas, and S. Wineburg (Eds.), Knowing Teaching and Learning History: National and International Perspectives (pp. 19-37). New York: New York University Press.

Seixas, P. (2016). Translation and its discontents: key concepts in English and German history education, Journal of Curriculum Studies, 48:4, pp. 427-439.

Shipman, T. (2 January 2014). Michael Gove blasts 'Blackadder myths' about the First World War spread by television sit-coms and left-wing academics'. Daily Mail. Retrieved from http://www.dailymail.co.uk/news/article-2532923/Michael-Gove-blasts-Blackaddermyths-First-World-War-spread-television-sit-coms-left-wing-academics.html

Tanner, J. (Ed.). (August 2013). Do Mention The War: Will 1914 Matter in 2014? (British Future). Retrieved from http://www.britishfuture.org/wpcontent/uploads/2013/08/BRF Declaration-of-war-report_P2 Web-1.pdf

Wallis, J. (2015). "Great-grandfather, what did you do in the Great War?" The Phenomenon of Conducting First World War Family History Research. In B. Ziino B (Ed.), Remembering the First World War (pp. 21-38). Abingdon: Routledge.

Watson, A. (2006). Self-deception and Survival: Mental Coping Strategies on the Western Front, 1914-18, Journal of Contemporary History, 41:2, pp. 247-268.

Wilson, A. and Hollis, G. (2007). How do we get better at going on trips? Planning for progression outside the classroom, Teaching History, 126, Outside the Classroom Edition, pp. 22-27.

Wineburg, S. (2001). Historical Thinking and Other Unnatural Acts: Charting the Future of Teaching the Past. Philadelphia, PA: Temple University Press.

Wineburg, S. (2007). Unnatural and essential: the nature of historical thinking, Teaching History, 129, Disciplined Minds Edition, pp. 6-11.

Winter, C. (2009). Tourism, Social Memory and the Great War, Annals of Tourism Research, $36: 4$, pp. 607-26.

Winter, C. (2011). Battlefield Visitor Motivations: Explorations in the Great War Town of Ieper, Belgium, International Journal of Tourism Research, 13, pp. 164-176.

Winter, J. (2006). Remembering War: The Great War Between Memory and History in the Twentieth Century. New Haven, CT: Yale University Press.

Winter, J. and Sivan, E. (Eds.). (2009). War and Remembrance in the Twentieth Century. Cambridge: Cambridge University Press. 
${ }^{\mathrm{i}}$ My thanks to the anonymous peer-reviewers of this article as well as Simon Bendry, Sarah Bulmer, Lindsey
Dodd, Mark Sheehan, Dan Todman, and James Wallis for their input into earlier drafts.
ii For more information on the FWWCBTP please refer to the programme website:
http://www.centenarybattlefieldtours.org (accessed 5 August 2016).

iii It is worth noting that the FWWCBTP is working with schools from England only. This could be interpreted as being in contradiction to official government claims of a 'truly national commemoration' of the war. See Mycock (2014).

iv Key Stage 3 (KS3) is the legal term for the three years of schooling in maintained schools in England and Wales normally known as Year Seven, Year Eight and Year Nine, when pupils are aged between 11 and 14 years old.

${ }^{v}$ For more on Op Reflect see https://www.gov.uk/government/news/remembering-the-battle-of-the-sommeoperation-reflect (accessed 15 August 2016).

${ }_{\mathrm{vi}}$ Either the In Flanders Field museum at the Cloth Hall in Ieper and/or the Passchendaele Memorial Museum in Zonnebeke.

vii For more information, please see http://www.comingworldrememberme.be/en/the-land-art-installation (accessed 6 July 2017).

viii The programme is designed to continue in the classroom. However, only pre- and post-tour classroom observations would enable definitive conclusions to be made about the impact of the programme beyond the tour itself.

ix See http://www.centenarybattlefieldtours.org/information/media/latest-news-and-press-releases/the-firstworld-centenary-battlefield-tours-programme's-key-objectives/ (accessed 28 July 2017).

${ }^{\mathrm{x}}$ At the Conservative Party conference in 2010, Gove advocated that all pupils in Britain should learn 'our island story' where the study of Britain's historic struggles are the only way 'we properly value the liberties of the present' (Gove, 5 October 2010).

xi See, for example, work by Cooper \& Chapman (2009), Husbands, Kitson \& Pendry (2003), Lee (2011), Seixas $(1999 ; 2016)$ and Wineburg $(2001 ; 2007)$.

xii A useful summary of the literature engaging with concepts such as 'collective remembrance', 'cultural remembrance', and 'sites of memory' can be found in Heathorn, 2013, pp. 11-14.

xiii The AHRC-funded research project The First World War in the Classroom laid much of the methodological groundwork for this project. Scates (2006) provided an important starting point for considering how to research the experience of battlefield visits. In addition, methodological insight was gleaned from scholars working in the fields of Tourism Research, Critical Heritage Studies, and Historical Geography (Baldwin \& Sharpley, 2009; Dunkley et al, 2011; Iles, 2006, 2008; Miles, 2013; Seaton, 2000, 2002; Winter, 2009, 2011). Hopkins (2010) also provides an important understanding of the methodological and ethical issues that arise in researching young people's engagement with the different places they inhabit.

xiv The survey was compiled by the author in collaboration with the former FWWCBTP Programme Director, Jerome Freeman, alongside Anna Warburton and Rebecca Hale from the IoE, and in consultation with the AHRC-funded 'The First World War in the Classroom' Academic and Teacher steering committees. The response rate for the survey was $86 \%$.

${ }^{x v}$ The 681 pupils who responded to the survey identified as: $55 \%$ female and $45 \%$ male; predominantly in years 9,10 and 11 (age $13-16 ; 78.4 \%$ ) at the time of the tour; 'white British' (83\%); and having 'no religion' (44.9\%). Those who did select a religious affiliation were majority 'Christian - all denominations' (39.9\%). Just over 16\% identified as being of minority ethnic origin (including white other), lower than the national statistic (as of January 2015) where $26.6 \%$ of pupils in state-funded secondary schools were classified as being of minority ethnic origin (DfE, 2015, p. 7).

xvi Year 9 male student, tour observation, February 2015.

xvii http://www.centenarybattlefieldtours.org/about-us/programme-awards/ (accessed 10 April 2017).

xviii 'Ministers aim to build 'empire 2.0' with African Commonwealth', The Times, 6 March 2017. See

https://www.thetimes.co.uk/article/ministers-aim-to-build-empire-2-0-with-african-commonwealth-after-brexitv9bs6f6z9 (accessed 11 April 2017).

xix Year 11 male student, focus group 1, 2015.

${ }^{x x}$ Year 9 female student, tour observation, February 2016.

xxi The three tour observations made by the author in 2015, 2016 and 2017 took place relatively early in the annual tour season cycle. The author was told by the FWWCBTP team that these occurrences of army-led face painting etc. were stopped each season as they were deemed inappropriate to the tour. It remains unclear what pre-tour discussion takes place between the FWWCBTP and the MoD about the way the latter contributes to the tour content.

xxii Year 10 female student, focus group 1, 2015. 
xxiii See http://www.bbc.co.uk/news/av/education-40745503/students-make-a-song-in-memory-of-a-world-war-isoldier. The song can be heard via YouTube: https://www.youtube.com/watch?v=yAZN3v2cxWA (accessed 26 January 2018).

xxiv Year 10 male student, tour observation, February 2015.

xxv See http://www.cwgc.org/find-war-dead.aspx and https://livesofthefirstworldwar.org (accessed 10 April 2017).

xxvi Research has also highlighted how the treatment of the First World War in English classrooms/national curriculum does not always develop critical thinking about the war in a broader scheme of lessons (Pennell, 2016).

xxvii For more information on Legacy 110 see: http://www.centenarybattlefieldtours.org/legacy-110/legacy-110post-visit-commemorative-projects/ (accessed 10 July 2017).

xxviii For more information on this CWGC resource see: http://cwgc-virtual-cemetery.org/cwgc-resources/ (accessed 10 July 2017).

xxix Year 12 female student, focus group 2, 2015,

xxx Year 10 male student, tour observation, February 2015.

xxxi Two Year 12 students (one male and one female), focus group 2, 2015.

xxxii It is a shame that the programme ends in 2019 when perhaps critical reflection on the war and its place in commemorative culture could be achieved beyond the stultifying atmosphere of the centenary.

xxxiii Year 10 female student, focus group 1, 2017.

xxxiv Year 12 female student, focus group 2, 2015. 